\title{
Librarians working with the legislative process can make a difference
}

\author{
By Gail Junion-Metz
}

Cleveland State University

Since the first ACRL chapter was formed in 1952, chapters have played an important role within ACRL. That role includes providing continuing education opportunities at the local level, providing a forum for discussion of issues of relevance across the profession, as well as providing visibility for the association at the local level. Chapters around the country, which include colleagues in Canada, have been doing this during the past decades in varying degrees and in varying ways. What is being said and done at the chapter level is indicative of what is or will be happening within the profession and the association. The purpose of this column is to share some of the interesting things being said and done in ACRL chapters which have an impact on the profession.

This first column will focus on the noticeable increase in chapter activities related to legislative efforts and political awareness. Although not the most riveting to write and read about, political activities are highly important to both chapters and the association. Although much of recent chapter political activity has come about due to the ACRL Legislation Committee's request for the establishment of chapter legislative liaisons as well as due to the upcoming White House Conference, many chapters already had an impressive history of such activity.

Chapters Council, and consequently chapters, have been involved from the beginning with the ACRL Government Relations Committee in planning and implementing the ACRL Legislative Network. Just now underway, the network, composed of Government Relations Committee liaisons and chapter representatives, will work together to affecț changes in attitude and funding for academic libraries. This network should continue to work for the chapters, should work for ACRL, and is already being used as a model by other associations. (Ed note: See May 1991 C\&RL News for a fuller description of the ACRL Legislative Network.)

\author{
and Ray E. Metz
}

Case Western Reserve University

Chapters have been meeting with various state legislators on State Legislative Days in states like Virginia and Michigan. During the day academic librarians have an opportunity to meet with their state legislators on academic library concerns. Many chapters not already holding these important meetings are planning them. Other states have been holding Governors Conferences toward the same end. Again, this effort on the state level should be emulated at the national level more strongly than is currently being done. During times of fiscal retrenchment, increased efforts to raise the consciousness of legislators, involving a wider number of librarians, are needed if academic priorities and concerns are to be heard. Such national efforts involving wider participation should be ongoing and not just take place during years when a White House Conference is being planned.

Chapters are inviting politically aware speakers to speak at local meetings in an effort to gain knowledge of the political process and to map out realistic strategies for making authorities aware of the needs of academic libraries. Rep. Major Owens and Herb White are two such speakers in increased demand. At one such meeting Rep. Owens's topic was "What's good for libraries is good for the country and the importance of shaping the White House Conference agenda." Both speakers stress the need for more political action and political thinking in the profession. Both also stress the importance of taking advantage of the upcoming White House Conference to influence national thinking on academic library issues and funding.

Many chapters are making concentrated efforts to make sure that academic librarians are selected as representatives to the White House Conference by sending chapter members lists of academic librarians who are willing to be nominated. These nomination campaigns have yielded excellent results so far. White House Preconferences at the state level have been well attended by academic librarians representing ACRL chapters. The asso- 
ciation should communicate in coming months with academic librarian delegates attending the White House Conference to coordinate the academic library agenda to be discussed at the conference.

Many White House Preconferences have brought forth resolutions supporting NREN thanks to ACRL chapter members. Chapters Council had presentations on this important piece of legislation during 1990 and the awareness taken back to the state level has produced results. Many chapters are actively discussing the ramifications of NREN at local programs and will be ready to aid in any national effort.
Chapters are meeting with their state librarians to find out how collection and budget statistics can be used to demonstrate the importance of library legislation. Librarians are also meeting with business and academic leaders in an effort to widen the circle of those aware of academic library concerns.

As chapters continue to step up their political activities and state-level political awareness increases, the membership of ACRL will come to expect an increased political agenda at the national level. Future association planning should take into account these expectations as well as the political influence that can be generated at both the local and national level and use both equally to further the goals of the profession and the association.

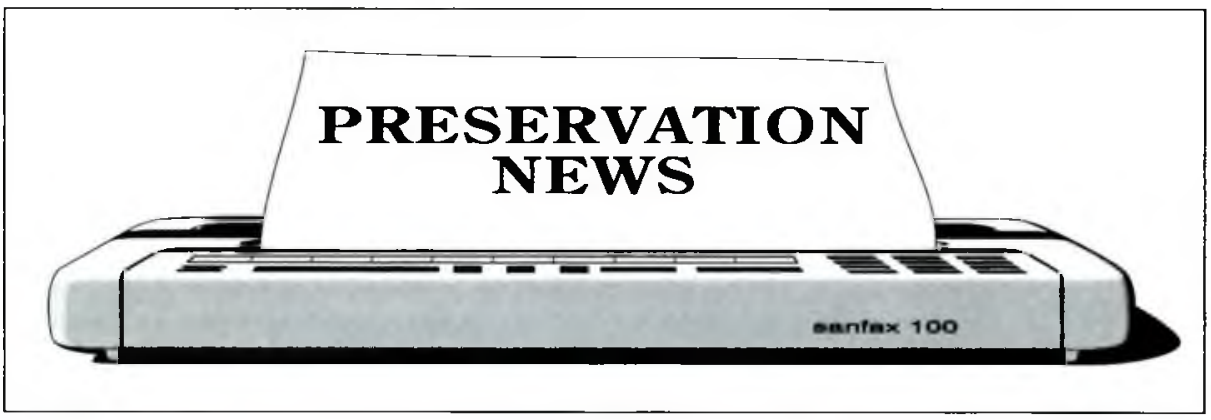

\title{
Prepared by Barbara Brown
}

\author{
College Libraries Committee \\ Commission on Preservation and Access
}

- Columbus, Ohio. The January 1991 issue of Preservation Issues, a publication of the State Library of Ohio, contains an excellent brief article by Dina Schoonmaker on "Oberlin College Libraries: A History of Preservation" in which she describes the growth of the preservation program at Oberlin. To obtain a copy of this issue or to be placed on the mailing list, contact Miriam Kahn, Preservation/ Conservation Consultant, State Library of Ohio, 65 South Front Street, Columbus, OH 43266-0334, (614) 644-1972.

- Dawson, Pennsylvania. The Giant Brittle Book exhibit (produced by the Commission on Preservation and Access) is on the road again and will appear at the Pittsburgh Regional Library Center Spring Conference in May, at the Ohio State University Libraries in October, and at the American Academy of Religion/Society of Biblical
Literature annual meeting in Kansas City in November. The Giant Brittle Book is available free of charge, except for shipping charges. For more information contact Trish Cece, communications assistant, at the Commission on Preservation and Access, 1785 Massachusetts Avenue, NW, Suite 313, Washington, DC 20036-2117.

- Washington, DC. The May 1991 issue of the Commission on Preservation and Access newsletter contains a list of publications available from the Commission. The form should be used to help expedite orders for the Commission's reports. To request copies, call or write Trish Cece, communications assistant, at the Commission on Preservation and Access, 1785 Massachusetts Ave., NW, Suite 313, Washington, DC 20036-2117; (202) 483-7474. 